\title{
Functional Groups and Individual Phenolic Compounds in Different Fractional Polarities Extracts of Rhizophora apiculata
}

\author{
Rashidi Othman ${ }^{1, *}$, Razanah Ramya ${ }^{1}$, Norazian Mohd. Hassan ${ }^{2}$ and Suhair Kamoona ${ }^{3}$ \\ ${ }^{1}$ International Institute for Halal Research and Training (INHART), Herbarium Unit, Department of Landscape \\ Architecture, Kulliyyah of Architecture and Environmental Design, International Islamic University Malaysia, \\ 53100 Kuala Lumpur, Malaysia \\ ${ }^{2}$ Department of Pharmaceutical Chemistry, Kulliyyah of Pharmacy, International, Islamic University Malaysia, \\ 25200 Kuantan, Malaysia \\ ${ }^{3}$ Department of Pharmacy, Al-Manara College for Medical Sciences, Maysan, Iraq
}

\begin{abstract}
The mangrove forest is often regarded as an unpleasant environment with less intrinsic values. Rhizophora apiculata has an important value as it provides several benefits to people, for example, it is a traditional medicinal plant that is also used in construction, as a source of food, dye and so forth. This study aims to identify types of functional groups and individual phenolic compounds from $R$. apiculata. An analytical method for $R$. apiculata was developed with different fractional extracts from water extraction. The result from the FT-IR analysis presented all fractional extract detected with different types of functional groups. The results revealed that four types of individual phenolic acids, which are Caffeic acid, Vanillic acid, trans-p-Coumaric acid and Ferulic acid, were detected in ethyl acetate and butanol extracts. However, none of the phenolic acids was detected in petroleum ether extract. All the phenolic acids detected in the study have not been exploited to their full potential. More research on optimizing the isolation and purification of these pigments as well as their usage in food systems is needed to enable their use in food applications or textile industries.
\end{abstract}

Keywords: Phenolic compound, phenolic acid, R. apiculata, HPLC, FT-IR.

\section{INTRODUCTION}

Rhizophora apiculata from the family Rhizophoraceae are known as red mangroves or "bakau minyak" in Malaysia and arewidespread throughout tropical and subtropical areas from the African east coast to Asia, Australia and Pacific Ocean [1]. Rhizophora is derived from the Greek word taken from its characteristic where Rhizo from the word rhiza means root while phora from the word phoros means bearing [2]. The $R$. apiculata communities inhabit the intertidal wetland zone that can reach 30 to $40 \mathrm{~m}$ in height and with stem diameters thatare often about 15 to $35 \mathrm{~cm}$ taken just above the highest prop root. This mangrove plant's flowering period is from August until December in the southern hemisphere while from February until June in the northern hemisphere [1]. As compared to other Rhizophora species, R. apiculata appears more prevalent in estuaries influenced by larger and more continuous freshwater flows [1-3]. From ecological aspects, this stilt mangrove probably has the greatest value for environmental benefit as it plays a vital role in supporting marine food chains,

*Address correspondence to this author at the International Institute for Halal Research and Training (INHART), Herbarium Unit, Department of Landscape Architecture, Kulliyyah of Architecture and Environmental Design, International Islamic University Malaysia, 53100 Kuala Lumpur, Malaysia; Tel: +6012 6644772; Fax: +603 61964864; E-mail: rashidi@iium.edu.my

ISSN: 2223-3806 / E-ISSN: 1927-5951/20 protecting coastal areas and improving water quality as well as in providing a balanced ecosystem [4, 5]. [6] reported that $R$. apiculata leaf tissues were detected with a higher concentration of copper, iron, zinc and lead compared to other mangrove species that were studied. Meanwhile, $R$. apiculata provides direct benefit to people since it is used for fuelwood, construction, medicinal purpose, tannin and dyes as well as an attraction site for ecotourism. $R$. apiculata contains secondary products including alkaloids, glycosides, essential oils and other organic constituents [7] to cure both infectious and non-infectious diseases in many people in Asia and Africa [8]. The alkaline extract from the leaf of $R$. apiculata inhibits the HIV replication and HIV-induced cytopathic effects. The substance responsible for the anti-HIV activity is an acid polysaccharide [9]. Besides, for tannin in the leather industry, the excellent inhibitive action of mangrove tannin is mainly attributed to the presence of hydroxyl groups as well as the interaction with rings containing conjugated bonds and $\pi$ electrons, which enable chemisorption of tannin molecules on the metal surface [10]. A discovery of $R$. apiculata extract contains protein, phenolic group and tannin [11]. Other compounds such as triterpenes and diterpenoids were isolated from this plant and a phenolic compound found in the pyroligneous acid of $R$. apiculata was used for antioxidant activities that are important for the body to (C) 2020 SET Publisher 
cure diseases such as inflammation, cardiovascular diseases, aging and so forth [3]. Phenolic compounds can be described as simple aromatic phenols, hydroxyl and substitute benzoic acids and aldehydes, hydroxy and substituted cinnamic acid, coumarin, tannin and flavonoids [12] that are comprised of a hydroxyl group $(-\mathrm{OH})$ bonded directly to an aromatic hydrocarbon group [13]. Phenolic acids are a subclass of larger phenolic categories in food plants i.e. ester or glycosides that are conjugated with other natural compounds (flavonoid and alcohol), which contain phenolic ring or at least one organic carboxylic acid [14]. The phenolic compounds have several properties such as enzyme inhibition, anti-tumor promoting activity and inhibition of metabolic activities that produce superoxide, which contributes to the traditional medicine [7]. Therefore, this study aims to explore the functional groups and individual phenolic compounds from $R$. apiculata leaves extracts.

\section{MATERIALS AND METHODS}

\section{Sample Preparation}

The leaves of the Rhizophora apiculata were collected and a random $1000 \mathrm{~g}$ fresh weight sample was immediately frozen at $-20^{\circ} \mathrm{C}$. The leaves samples were freeze-dried for three days, after which the samples were ground into a fine powder and stored at $20^{\circ} \mathrm{C}$ until further analysis.

\section{Extraction of Chemical for Phenolic Compounds}

The extraction procedure essentially followed the methods described by $[15,16]$ with the following modifications. For each sample, $10 \mathrm{~g}$ of powdered freeze-dried material was mixed with $100 \mathrm{ml}$ of distilled water and then the sample was incubated in an oven at about $60^{\circ} \mathrm{C}$ for $30 \mathrm{~min}$ before being allowed to stand overnight, in darkness at room temperature, before the clear supernatants were re-extracted with different solvents polarities; petroleum ether, ethyl acetate and butanol.

\section{Separation of Phenolic Compounds}

The phenolic compounds were isolated from $R$. apiculata water extract according to the method of [16]. The crude extraction (clear supernatant) was performed using petroleum ether, ethyl acetate and butanol, using a funnel separator. For further analysis, the final concentration was resuspended with $5 \mathrm{ml}$ of methanol in tubes then capped and sealed with parafilm to exclude oxygen and immediately stored at - $20^{\circ} \mathrm{C}$ until subsequent analysis. $50 \mu \mathrm{L}$ of the redissolved sample was then transferred in a vial for further analysis by Fourier transform infrared (FT-IR) spectroscopy, total phenolic compound (TPC) and high-performance liquid chromatography (HPLC).

\section{Determination of Phenolic Functional Groups}

The sample spectra were recorded on an FT-IR spectrometer in the range of $400-4000 \mathrm{~cm}^{-1}$ using Thermo Scientific FT-IR Spectrometer (Nicolet iS50). The software used for FT-IR data collection was OMNIC version 9.2 (Thermo Scientific). Five hundred microlitres of the sample were poured onto the ATR crystal [17].

\section{Determination of Total Phenolic Content}

TPC determination used the Folin-Ciocalteau assay as reported by [18]. $90 \mu \mathrm{L}$ of Folin-Ciocalteu reagent was diluted in deionised water $(20 \% \mathrm{v} / \mathrm{v})$ and was placed in each well of a flat-bottomed 96-well clear microplate. After that, $1.0 \mathrm{mg} / \mathrm{g} \mathrm{DW}$ of the sample that was diluted with distilled water $(1000 \mu \mathrm{g} / \mathrm{mL})$ and incubated at room temperature for 5 minutes. Next, 90 $\mu \mathrm{L}$ of sodium carbonate in deionised water $(7.5 \% \mathrm{w} / \mathrm{v})$ was mixed and incubated for two hours at room temperature. The absorbance of extracts and standard was then read at $\lambda \max =725 \mathrm{~nm}$ against a blank (deionised water without extract or standard) using a TECAN microplate reader.

The total phenolic compound (TPC) was determined using a gallic acid calibration curve whereas the domain for gallic acid (GAE) calibration curves was calculated concerning the dilution factor $=11$. Twofold serial dilution (five different concentrations) was performed in $30 \mathrm{~mL}$ glass vials using a micropipette, and $1.0 \mathrm{mg} / \mathrm{g}$ DW of each concentration (GAE) per gram dry weight sample \pm standard error of the mean (SEM). The TPC concentrations were expressed in terms of a microgram GAE per $1.0 \mathrm{~g}$ dry weight of freeze-dried matter ( $\mu \mathrm{g} \mathrm{GAE/g} \mathrm{DW).}$

\section{HPLC Analysis of Individual Phenolic Compounds}

The HPLC analysis of phenolic acids was performed on an Agilent 1200 series rapid resolution LC system (Agilent Technologies, Palo Alto, CA, USA) that comprises of a binary pump with autosampler injector, micro vacuum degassers, thermostatted column compartment and a diode array detector (DAD) [21]. The column used was a Zorbax Eclipse XDB- $\mathrm{C}_{18}$ end-capped $5 \mu \mathrm{m}, 4.6 \times 150 \mathrm{~mm}$ reverse phase column 
(Agilent Technologies, USA). For the analysis, a linear gradient elution was used, with the two mobile phases consisting of $1 \%$ formic acid in water/ acetonitrile $90: 10$ $\mathrm{v} / \mathrm{v}$ (phase A) and acetonitrile (phase B) using the following gradient: 0-20 min, linear gradient from $0 \% B$ to $40 \% \mathrm{~B} ; 20-25 \mathrm{~min}$, linear gradient from $40 \% \mathrm{~B}$ to $60 \% \mathrm{~B} ; 25.10-35 \mathrm{~min}$, linear gradient from $100 \% \mathrm{~B}$ to $100 \% \mathrm{~B}$ and $35.10-40 \mathrm{~min}$, isocratic of $0 \% \mathrm{~B}$. The temperature of the column was set at $25^{\circ} \mathrm{C}$. The injection volume was $20 \mu \mathrm{L}$, and the flow rate was set at $1.0 \mathrm{~mL} \mathrm{~min}{ }^{-1}$. Phenolic acid standards of Caffeic acid, Ferulic acid, trans-p Coumaric acid, 2-Coumaric acid, 4-Coumaric acid, Hydroxybenzoic acid and Vanillic acid were purchased from Sigma-Aldrich. The individual phenolic acids were detected at the wavelength of maximum absorption of the phenolic acids in the mobile phase at $280 \mathrm{~nm}$ by using photodiode array detection. Individual phenolic acid concentrations were calculated by comparing their relative proportions, as reflected by integrated HPLC peak areas. The individual phenolic acid compound concentrations were expressed in terms of a microgram per $1.0 \mathrm{~g}$ dry weight of freeze-dried matter $(\mu \mathrm{g} / \mathrm{g} D W)$.

\section{RESULTS AND DISCUSSION}

\section{FT-IR Analysis of Phenolic Functional Group}

The FT-IR analysis of water extract for $R$. apiculata leaves showed the presence of aliphatic hydrocarbon in petroleum ether fractional extract, peak at 2932.82 $\mathrm{cm}^{-1}$ (Table 1; Figure 1). The peak at $2930 \mathrm{~cm}^{-1}$ was assigned to a $\mathrm{CH}_{2}$ asymmetric bond. The second solvent, ethyl acetate, fractional extract, was detected with three different functional groups of aromatic hydrocarbon, olefin and aromatic ether with major peaks at $1991.84 \mathrm{~cm}^{-1}, 1673.86 \mathrm{~cm}^{-1}$ and $1283.14 \mathrm{~cm}^{-1}$, respectively (Table 1; Figure 1). The peak at 1700 $2000 \mathrm{~cm}^{-1}$ was assigned to a $\mathrm{C}-\mathrm{H}$ bond (aromatic hydrocarbon), $1620-1680 \mathrm{~cm}^{-1}$ assigned to a $\mathrm{C}=\mathrm{C}$ bond (olefin) and $1230-1270 \mathrm{~cm}^{-1}$ to a $-\mathrm{C}-\mathrm{O}-\mathrm{C}-$ bond (aromatic ether). The last solvent, butanol fractional extract, was detected with only phenol group at $1204.01 \mathrm{~cm}^{-1}$ (Table 1; Figure 1). The peak at 1200 $\mathrm{cm}^{-1}$ was assigned to $-\mathrm{OH}$ bond (phenol). Those groups were observed in FT-IR spectra in all fractional extracts for $R$. apiculata. The excellent inhibitive action of $R$. apiculata is mainly attributed to the presence of hydroxyl groups [20]. The most common extraction solvents were alcohols (methanol and ethanol), acetone, diethyl ether and ethyl acetate have been used for phenolic compound extract [21]. In this study, most of the functional groups were detected in ethyl acetate fractional extract followed by petroleum ether and butanol extracts. [17] reported that phenol could be found in the range between $900-1680 \mathrm{~cm}^{-1}$. Therefore, the peak frequency at $1200 \mathrm{~cm}^{-1}$ was identified as the phenol group. This was supported by [22] who mentioned that the presence of alcohol, phenols, carboxylic acid and siloxanes indicated that lignocellulose degradation.

\section{HPLC Analysis of Individual Phenolic Compound}

$R$. apiculata was found to have the total phenolic content of $977.90 \pm 2.13 \mu \mathrm{g} \mathrm{GAE} / \mathrm{g}$ DW whereas individual phenolic content analysis performed by HPLC system detected at least four major peaks: Caffeic acid, Vanillic acid, trans-p-Coumaric acid and Ferulic acid as shown in Table 2. The highest amount for individual phenolic was Ferulic acid $(1.56 \pm 0.01$ $\mu \mathrm{g} / \mathrm{g} D W$ ) in ethyl acetate extract, whereas, the lowest was trans-p-Coumaric acid $(0.02 \pm 0.00)$ also in ethyl acetate extract. Polyphenols can be defined as molecules having more than one hydroxyl group in their structure. They are ubiquitous molecules which act as secondary metabolites in plants [23]. Polyphenols can be structurally classified as flavonoids or nonflavonoids and can have a simple structure like phenolic acids or very complex like tannins. Nonflavonoids include phenolic acid derivatives, stilbenes, tannins and lignins are mostly colorless compounds or

Table 1: FT-IR Peak Values of $R$. apiculata in Water Extraction Different Fractional Polarities Extracts

\begin{tabular}{|c|c|c|c|c|c|}
\hline $\begin{array}{c}\text { Solvent } \\
\text { extracts }\end{array}$ & $\begin{array}{c}\text { Peak (wave number } \\
\left.\mathbf{c m}^{-1}\right)\end{array}$ & Intensity & Bond & $\begin{array}{c}\text { Gunctional group } \\
\left(\mathbf{c m}^{-1}\right)\end{array}$ \\
\hline \hline $\begin{array}{c}\text { Petroleum } \\
\text { ether }\end{array}$ & 2932.82 & 99.932 & $\mathrm{CH}_{2}$ asymmetric & Aliphatic hydrocarbon & 2930 \\
\hline \multirow{2}{*}{ Ethyl acetate } & 1991.84 & 99.843 & $\mathrm{C}-\mathrm{H}$ & Aromatic hydrocarbon & $1700-2000$ \\
\cline { 2 - 6 } & 1673.86 & 98.630 & $\mathrm{C}=\mathrm{C}$ & Olefin & $1620-1680$ \\
\cline { 2 - 6 } & 1283.14 & 98.816 & $-\mathrm{C}-\mathrm{O}-\mathrm{C}-$ & Aromatic ether & $1230-1270$ \\
\hline Butanol & 1204.01 & 97.907 & $-\mathrm{OH}$ & Alcohol & 1200 \\
\hline
\end{tabular}


a)

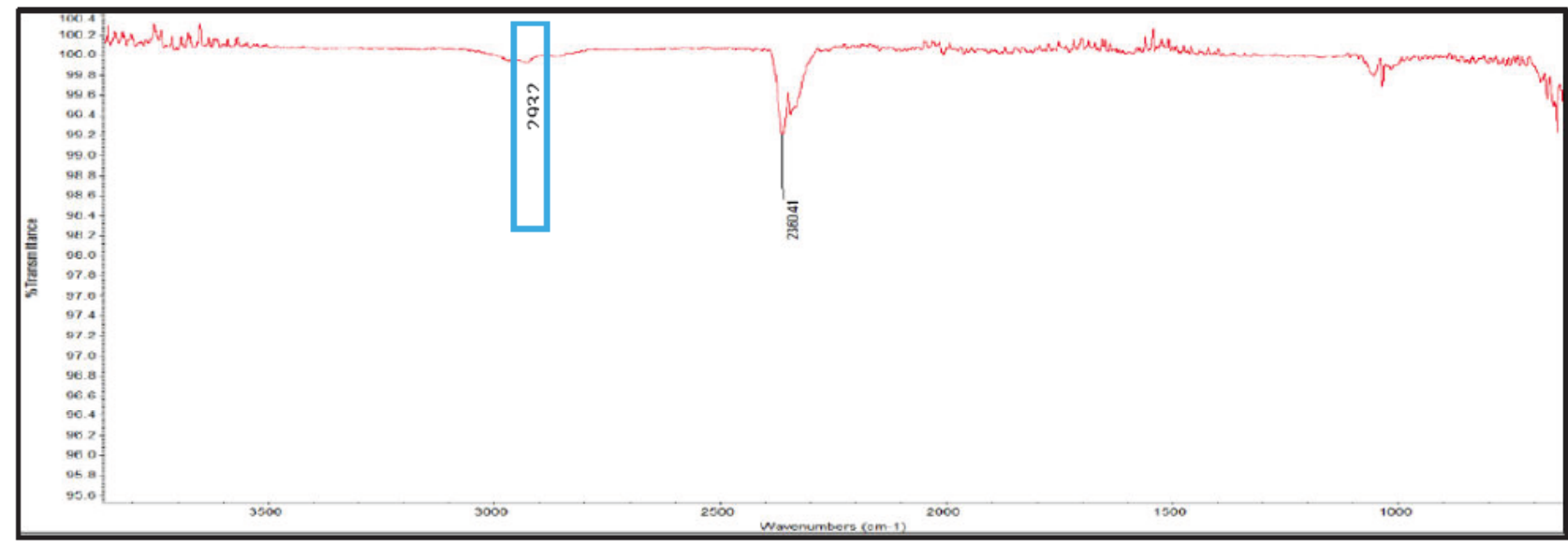

b)

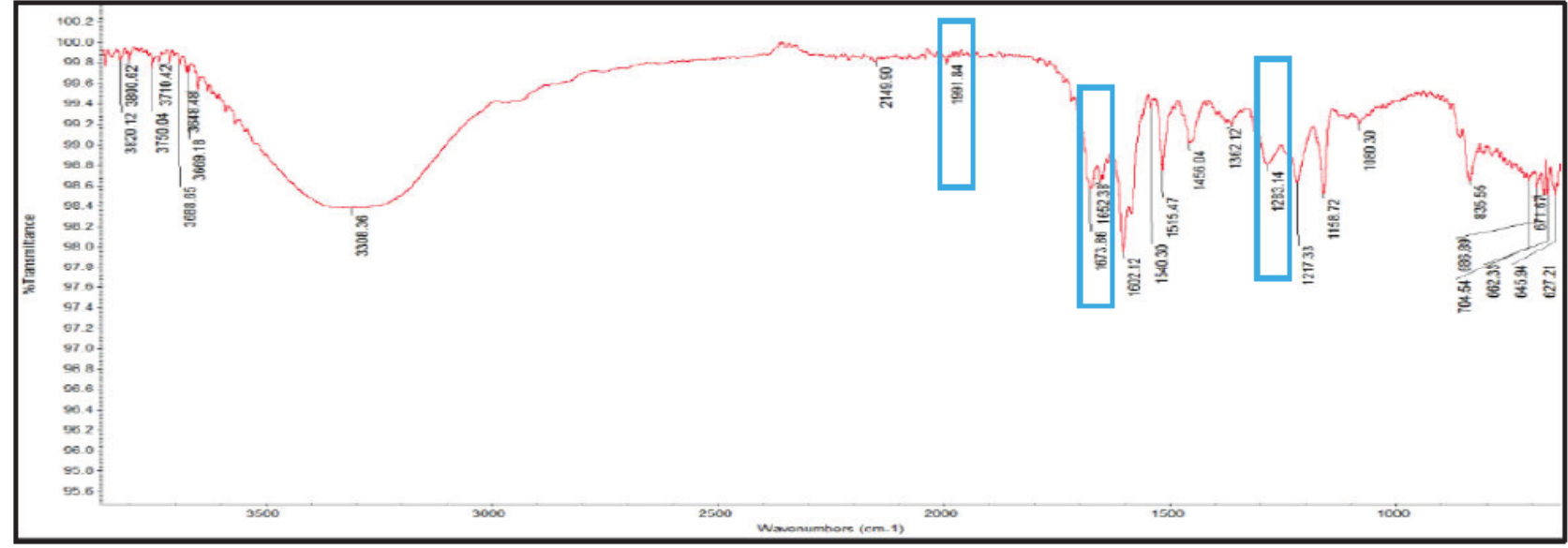

c)

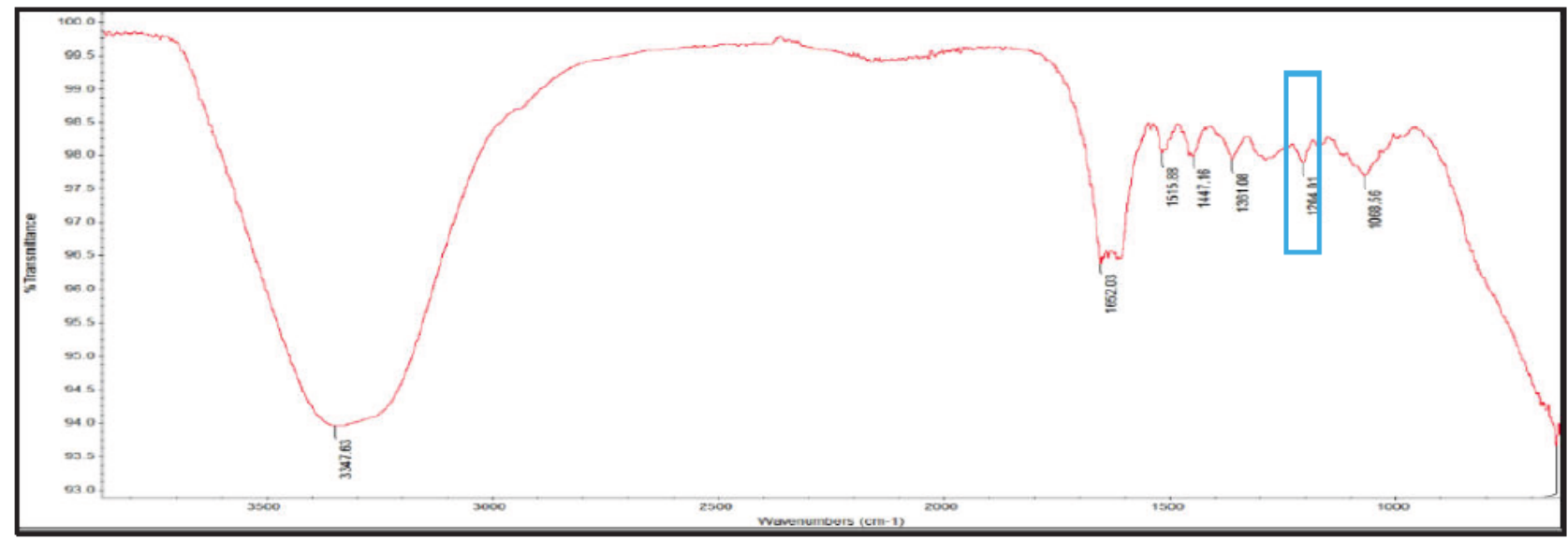

Figure 1: FT-IR peak values of $R$. apiculata in water extraction for (a) petroleum ether, (b) ethyl acetate and (c) butanol fractional extracts.

light yellow/brown and rarely contribute to the color of foods. Another group is flavonoids or colored polyphenols and also the polyphenols that produce color as a result of processing including fermentation, enzyme activity or heat [24]. The market for natural colorants for food applications is ever increasing. Consumers' preferences are simpler and cleaner labels for their foods and are seeking alternatives to synthetic ingredients. As a result, interest in natural products including natural colorants is obvious. Therefore, this study revealed the potential of polyphenols and polyphenol derived molecules as potential food colorants or active pharmaceutical ingredients.

\section{CONCLUSION}

The results from the FT-IR analysis presented the different types of functional groups that were detected in all the fractional extracts.. The results revealed that four types of individual phenolic acids, which are Caffeic acid, Vanillic acid, trans-p-Coumaric acid and Ferulic acid, were detected in ethyl acetate and butanol 
Table 2: Total ( $\mu$ g GAE/g DW) and Individual Phenolic Content ( $\mu \mathrm{g} / \mathrm{g} \mathrm{DW}$ ) of $R$. apiculata in Water Extraction for Different Fractional Polarities Extracts

\begin{tabular}{|c|c|c|c|c|c|c|c|c|}
\hline 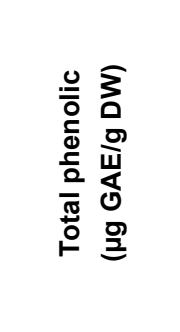 & 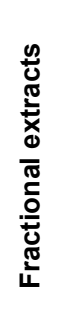 & 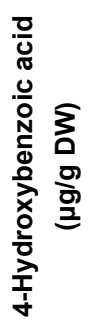 & 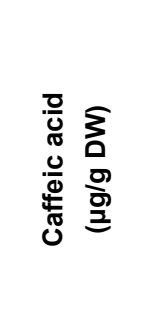 & 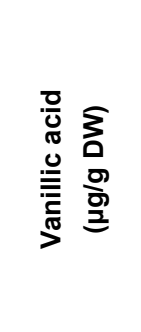 & 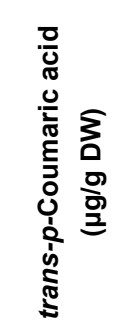 & 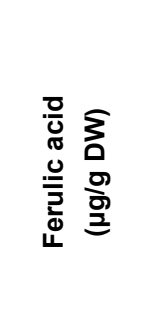 & 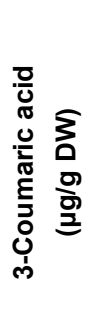 & 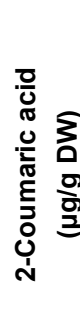 \\
\hline \multirow{3}{*}{$977.90 \pm 2.13$} & $\mathrm{PE}$ & ND & ND & ND & ND & ND & ND & ND \\
\hline & EA & ND & $0.45 \pm 0.00$ & $0.83 \pm 0.00$ & $0.02 \pm 0.00$ & $1.56 \pm 0.01$ & ND & ND \\
\hline & $B$ & ND & $0.10 \pm 0.01$ & $0.55 \pm 0.00$ & ND & $0.25 \pm 0.00$ & ND & ND \\
\hline
\end{tabular}

Note: PE (Petroleum ether); EA (Ethyl acetate); B (Butanol); ND (Not detected).

extracts. However, none of the phenolic acids was detected in petroleum ether extract.

All the phenolic acids detected in the study have not been exploited to their full potential. Usually, colorless polyphenols can give rise to colored products by virtue of the presence of enzymes or reaction with other substrates or both. More research is needed of these pigments potential applications especially in food systems to enable their future enhancement and enrichment in food applications, pharmaceutical ingredients as well as textile industries.

\section{ACKNOWLEDGEMENT}

This work was supported by the Ministry of Higher Education (MOHE) and International Islamic University Malaysia (IIUM) under Research Grant P-RIGS18-0010001.

\section{REFERENCES}

[1] Duke N. Rhizophora apiculata, R. mucronata, R. stylosa, R. x annamalai, R. x lamarkii (Indo-West Pasific stilt mangrove). In Species profiles Island Agroforestry. Elivitch C. (Ed.). Haluola, Hawaii, Permanent Agriculture Resource 2006.

[2] Wiart C. Medicinal plants of Asia and the Pacific, CRC Press 2006. https://doi.org/10.1142/5834

[3] Wu J, Xiao Q, Xu J, Li M, Pan J, Yang M. Natural products from true mangrove flora: source, chemistry and bioactivity. Nat Prod Rep 2008; 25: 955-981. https://doi.org/10.1039/b807365a

[4] Bandaranayake WM. Bioactivities, bioactive compounds and chemical constituents of mangrove plants. Wetl Ecol Manag 2002; 10(6): 421-452.

https://doi.org/10.1023/A:1021397624349

[5] Ramya R, Othman R, Yaman M. The concept of hima and harim in the application of mangrove ecosystem protagonist as potential ecological indicator for inorganic contaminants. In Ecological indicators in Islamic built environment. Othman
R, Mohd Hatta FA, Mohd Latiff NH, Ramya R, Mat Ali QA, Abu Yazid AF, Hanifah NA (Eds.), Kuala Lumpur, Institut Terjemahan \& Buku Malaysia 2016.

[6] Othman R, Ramya R, Baharuddin ZM, Hashim KSHY, Yaman M. Ecological indicator agents for inorganic contaminants state monitoring through Sonneratia alba, Avicennia alba and Rhizophora apiculata. J Tekno 2015; 77(30): 111-118. https://doi.org/10.11113/jt.v77.6874

[7] Abdul Halim A, Zainal Abidin N, Me R. A study of chemical compounds in Rhizophoha apiculata. Open Conf Proc J 2013; 4: 108-110.

https://doi.org/10.2174/2210289201304020108

[8] Muthulingam M, Chaitanya K. Phytochemical screening and cytotoxic effect of methanolic leaf extract of Rhizophora apiculaya blume against Michigan Cancer Foundation-7 breast cancer cell lines. Drug Invent Today 2018; 10(2): 2995-2998.

[9] Premanathan M, Arakaki R, Izumi H, Kathiresan K, Nakano $M$, Yamamoto $N$, Nakashima $H$. Antiviral properties of mangrove plant, Rhizophora apiculata Blume against human immunodeficiency virus. Antiviral Res 1999; 44(2): 113-122. https://doi.org/10.1016/S0166-3542(99)00058-3

[10] Kang W, Kassim M. A correlation study on the phenolic profiles and corrosion inhibition properties of mangrove tannings (Rhizophora apiculata) as affected by extraction solvents. Corros Sci 2001; 53: 569-574. https://doi.org/10.1016/j.corsci.2010.09.065

[11] Ravikumar B, Sarkar S, Davies JE, Futter M, GarciaArencibia M, Green-Thompson ZW, Jimenez-Sanchez M, Korolchuk VI, Lichtenberg M, Luo S, Massey DC, Mexzies F, Moreau K, Narayanan U, Renna M, Siddiqi F, Underwood BR, Winslow A, Rubinsztein D. Regulation of mammalian autophagy in physiology and pathophysiology. Physiol Rev 2010; 90(4): 1383-1435. https://doi.org/10.1152/physrev.00030.2009

[12] Zhou Y, Jiang J, Gao Y, Pang SY, Yang Y, Ma J, Yuan LP. Activation of peroxymonosulfate by phenols: Important role of quinone intermediates and involvement of singlet oxygen. Water Res 2017; 125: 209-218. https://doi.org/10.1016/i.watres.2017.08.049

[13] Othman R, Ramya R, Mohd Hassan N. Allelochemical composition and content of Acrostichum aureum, Stenochlaena palustris and Dicanopteris linearis. In Ferns: Ecology, Importance to Humans and Threats. Nowicki L, Kowalska A (Eds.), New York, Nova Science Publishers 2018; pp. 121-145. 
[14] Goleniowski M, Bonfill M, Cusido R. Phenolic acids. In Natural Product, Ramawat K, Merillon J (Eds.), Berlin Heidelberg, Springer 2013; p. 63. https://doi.org/10.1007/978-3-642-22144-6 64

[15] Aarabi A, Mizani M, Honarvar M, Faghihian H, Gerami A. Extraction of ferulic acid from sugar beet pulp by alkaline hydrolysis and organic solvent methods. J Food Meas Charact 2016; 10(1): 42-47. https://doi.org/10.1007/s11694-015-9274-z

[16] Bertin C, Yang X, Weston LA. The role of root exudates and allelochemicals in the rhizosphere. Plant Soil 2003; 256(1): 67-83.

https://doi.org/10.1023/A:1026290508166

[17] Silva S, Feliciano R, Boas L, Bronze M. Application of FTIRATR to Moscatel dessert wines for prediction of total phenolic and flavonoid contents and antioxidant capacity. Food Chem 2014; 150: 489-493. https://doi.org/10.1016/j.foodchem.2013.11.028

[18] Singleton V, Rossi J. Colorimetry of total phenolicswith phospho-molybdic-phosphotungstic acid reagents. Am J Enol Vitic 1965; 16: 144-158.

[19] Zhao H, Sun J, Fan M, Fan L, Zhou L, Li Z, Guo D. Analysis of phenolic compounds in Epimedium plants using liquid chromatography coupled with electrospray ionization mass spectrometry. J Chromatogr 2008; 1190: 157-181. https://doi.org/10.1016/j.chroma.2008.02.109

[20] Tan KW, Kassim MJ. A correlation study on the phenolic profiles and corrosion inhibition properties of mangrove tannins (Rhizophora apiculata) as affected by extraction solvents. Corros Sci 2011; 53(2): 569-574. https://doi.org/10.1016/j.corsci.2010.09.065

[21] James Z, Baharin A, Abdulkarim S, Abas F. Solvent and supercritical fluid extraction of catechin from Camellia Sinensis (tea) leaves for utilization as functional food ingredient. Int J Res Eng Technol 2016; 16(2): 21-33.

[22] Nishibe S. Bioactive phenolic compounds in traditional medicines. Pure Apply Chem 1994; 66(10): 2263-2266. https://doi.org/10.1351/pac199466102263

[23] Acosta-Estrada BA, Gutiérrez-Uribe JA, Serna-Saldivar SO. Bound phenolics in foods, a review. Food Chem 2014; 152 46-55. https://doi.org/10.1016/j.foodchem.2013.11.093

[24] Dabas D. Polyphenols as Colorants. Adv Food Technol Nutr Sci Open J 2016: SE(2): S1-S6. https://doi.org/10.17140/AFTNSOJ-SE-2-101 